\title{
The Treasury Bill Futures Market and Market Expectations of Interest Rates*
}

\author{
ALBERT E. BURGER, RICHARD W. LANG, and ROBERT H. RASCHE
}

E CONOMISTS and other analysts seek to measure expectations of future interest rates because such expectations have important effects on economic behavior. Changes in expectations can lead to changes in economic activity, both at the level of the individual firm or consumer, and at the level of the national economy. For example, interest rate expectations enter into investment decisions of firms, portfolio decisions of financial intermediaries and other investors, and borrowing decisions of state and local governments. If these groups alter their expectations of the future level of interest rates, changes in investment, portfolio, and borrowing decisions will occur which affect not only each group individually, but which also affect the level of economic activity in the economy as a whole. Consequently, policymakers and researchers have been interested in measuring market expectations of interest rates - first, to understand the behavior of economic units in individual markets, and second, to monitor changes in expectations which result from policy actions, in order to judge the impact which the policy may have on the economy.

For example, consider the discussion surrounding the recently aborted Federal income tax rebate. The argument for such a policy was that it would stimulate consumer spending, and thus stimulate aggrem gate output and employment. However, there was considerable concern that the policy would cause an upward revision of short-term interest rate expectations if there were general agreement that the Treas. ury would have to increase its borrowing substantially during the second half of 1977 to finance the increased deficit. Under such circumstances, much, if not all, of the alleged stimulus that would be pro. vided by the tax rebate could be offset by the negative impact of higher interest rate expectations on firms' decisions to invest in real capital. Such a negative effect arises because the higher the expected level of future interest rates, the less profitable the income stream associated with each particular investment project. The examination of such effects of policy

\footnotetext{
The authors gratefully acknowledge the assistance of Ms. Jeanne Rickey and the Statistical Department of the Chicago Mercantile Exchange for providing data used in this paper.
}

actions would be made much easier if market expectations of future interest rates were readily observable.

A considerable amount of economic research has been devoted to formulating measures of market expectations of interest rates, since data on expectations are not directly observable unless survey methods are used. Efforts at measurement have taken the form of everything from "informed judgement" to elaborate econometric models. Another means of obtaining an estimate of the level of short-term interest rates expected to prevail at some future date has become available since early 1976 . This method employs the yield quotations of the futures market in U.S. Treasury bills. These quotations, which are avallable on a daily basis, embody market expectations of future short-term interest rates. This paper focuses on the information about market expectations which can be obtained from yields on Treasury bill futures contracts.

\section{THE ROLE OF THE TREASURY BILL FUTURES MARKET}

The futures market in three-month U.S. Treasury bills was opened on the International Monetary Market of the Chicago Mercantile Exchange in January 1976, soon after the opening of a mortgage futtres market on the Chicago Board of Trade in October 1975. ${ }^{1}$ Both of these futures markets in financial instruments operate in essentially the same way as the traditional commodity futures markets. Futures trading in financial instruments allows the separation of the risk of unexpected interest rate movements from other types of risk. Futures contracts can be used to hedge against interest rate movements in order to protect actual or expected cash positions of market participants. Profits are thereby protected in much the same way as hedging in commodity futures markets protects against price finctuations of a particular commodity. Speculation is facilitated by the existence of futures markets, which allow the assumption of

\footnotetext{
iFor details on the Treasury bill futures market, see the accompanying section: "Characteristics of the Treasury Bill Futures Market."
} 


\section{Characteristies of the Treasury Bill Futures Market}

The Treasury bill futures narket began active wad ing on Jmary 6 , 1976 , in emiracts of thee-nomith

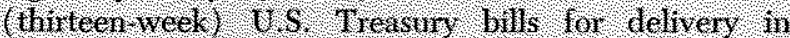
Mard, Twe, Septeniber, and Decenber, Ongrnally there were only fou conthacts Iraded, Whe latest being for delivery only one vear in die fabre, but in July 1976 the nimber of contracts was increased to six the latest being lor delivery eighteen month in the future

The stze of cach contract is 41 million, in lems of

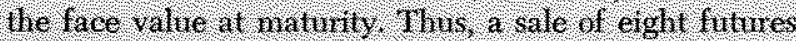
conitucts of Marde 1978 Measury bulls is a sale of

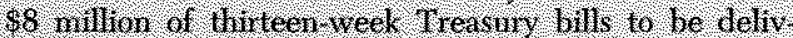
gred in Marel 1978 at an agred ypon price. Sim

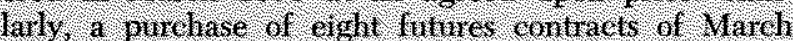

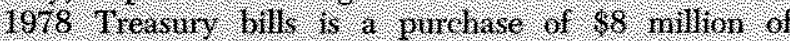

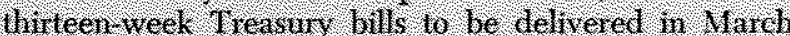
1978 at an agreed upon price. If held to delivery a

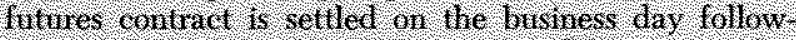
hing the last dav of lrading in he delvery nomth. Tutures Gading terminates on the second business day following the Treasury auction of three-month bils in We Inrd weel of the deliver nomh tor example. Warch 1978 Treasury bill fuhres conthats are deliv. eted in the thind wed of Mard, with the defvered

Detall on he 1 reasury bill filures market are contamed

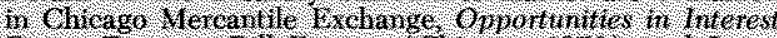
Thes: Treasmin bil t utures (Chicago, 1976 , and Inter rational Monetan Warket DWision, International Mone

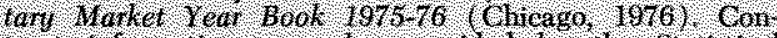
traet infortination was also provided 1 , the Statistical Departinent of the Ohieago Mercantile I reluatuge:
Treasury bills naraing at he end of three nombs (the thind wed of ine 1978)

Although the sibe of a single contract is of nillion, a person hiterested in buing or selling a contract an

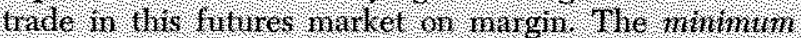
initial nugin is 41,500 ver contract, and he conmis. sion for execuing al order is 860 per contract by of setting an hitial buy ar sell arder hor lo de lelivery date, it is possllle to hade in. Treasiny lill fuhures contracts with far less noney lhan he 11 willon lace value of ench contract.

Phices in lhe Treasury bil maket are quoted on a Arseount basis, that is, at a priee lower. Mhan he face Valie, and prices in the Theasury bill finures narket are also quoled on a discount 1 hsis. 71 e interest eamed or a Treasuy bll, if held lo maturity, us libe diflerence

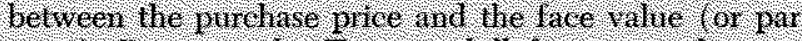

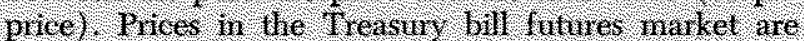
groted in temis of the INM I Intenurtional Whonetary

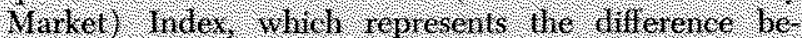

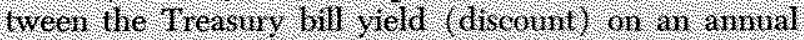
basis and 100 (face value or par)? Tor example.

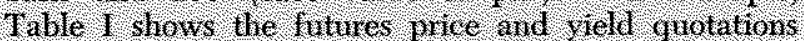
for Treasury bils on Mardi 14.1977 , as published by

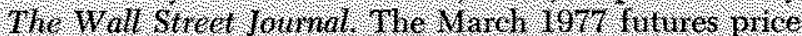
at the dose of trading ( he sertlenent price) was: 05.39. so that the interest rate ( yeld on a discomm basis) on we Mmeh 1977 contruet was 4.61 , petcent $(100-0539)$.

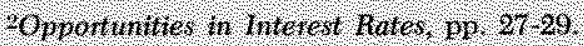

interest-rate risk by individuals willing to bear such risk in return for the possibility of making a profit. ${ }^{2}$

\section{Futures Markets, Information, and Market Expectations}

Trading in futures markets provides information to the cash market about the commodity being traded..$^{3}$ Prices of futures contracts for delivery of a

2For a discussion of the futures markets and the roles of hedg. ing and speculation, see Thomas A. Hieronymus, Economics of Fututes Trading: For Commercial and Personal Profit 2 nd ed. (New York: Commodity Research Buteat, Inc., 1977).

Uses of the Treasury bill futures matket in terms of hedging and speculation are basically the same as those of the mortgage futures market. In addition, a discussion of the costs and benefits of the Treasury bill futures market would be essentially the same as a discussion of the costs and benefits of the mortgage futures market. For such analyses of the mortgage futures market, see Neil A. Stevens, "A Mortgage Futures Market: Its Development, Uses, Benefts, and Costs," this Review (April 1976), pp. 12-19.

For a discussion of the effect of futures trading on information in spot markets, see Charles C. Cox, "Frutures Trading and Market Information," Joumal of Political Economy (December 1976), pp. $1215-37$. commodity at a future date provide market participants with information as to the expected pattern of future spot prices of this commodity. This is because information relating to the future state of the market for a particular commodity is utilized by market participants when determining the price at which they are willing to buy or sell futures contracts.

If a trader projects that a commodity's price will be different in the future than at the present time, he will buy or sell contracts for delivery of the commodity at some future date as if his projection were correct. Any trader who has better information about future spot prices than other market participants (or feels that he does) can attempt to make profits by trading on this information, with the result that such information is quickly incorporated into the prices of futures contracts. Thus, the interaction of all traders in the futures market provides price quotations which embody the market's expectations of the future spot prices that will prevail on various delivery dates. 
In the case of the futures market in Treasury bills, the yields on futures contracts indicate the pattern of interest rates expected by market participants to prevail in certain months in the future, given currently available information. Any expectation of future in terest rates, however arrived at, utilizes information about the current and expected values of variables that are thought to influence the behavior of interest rates. Such variables include measures of the current and future state of the econony, the supply and demand for credit, and the course of monetary and fiscal policy. The futures market in Treasury bills serves the role of a processor of this information. As new information about the course of key factors influencing interest rates becomes available, it is rapidly reflected in futures market prices. ${ }^{*}$

The expected interest rate for any date in the future which is embodied in the yield on current futures contracts is not necessarily the interest rate that will prevail at that future date. Market participants in the futures market do not have a crystal ball that foretells the future perfectly. Their decisions to buy or sell contracts are based on the information available at the present time. As new information becomes available, market participants may very well revise their expectations. The effect of new information - such as a change in the announced monetary targets, new budget projections, revised projections of the strength of economic activity, new pricing policies by OPEC, and so on - is reflected in changes in the prices of (and yields on) futtres contracts. Consequently, changes in market expectations can be identified by shifts in the patten of yields on futures contracts (futures rates). Sharp declines or increases in futures rates can be identified as changes in the expected level of future interest rates. Thus, a comparison of the quotations on futures contracts at two different points in time provides information on whether

tThis discussion does not imply that the Treasury bill futures market satisfies the "efficient market" hypothesis. In an "effi" cient market", all available infomation is utilized immediately by traders (and potential traders), new information is available to everyone at the same time, and new information is immediately incorporated into market prices and yields. The discussion in the paper implies only that some of the available information is nitilized by traders (or potential traders); and that new information which is utilized is quickly reflected in futures prices. This allows for information costs and imperfect infomation among market participants. For a general discussion of the "efficient market" model, see Oldrich A. Yasicek and John A. MoQnown, "The Eifcient Market Model," $F i$ nancial Analusts Journal (September-October 1972), pp. 7184. For a theoretical treatment, see Eugene F. Fama, "Efffcient Capital Markets: A Review of Theory and Empirical Work, Journal of Finance (May 1970), pp. 383-417; on Richard Roll, The Behavior of Interest Rates: An Application of the Efficient Market Model to U.S. Treasury Bitls (New York: Basie Books, Ine, 1970). market expectations have changed with regard to the future level of short-term rates. One implication of this is that it may be possible to assess the effect of a change in monetary or fiscal policy on market expectations of future short-term interest rates.

\section{Futures Rates and Expected Spot Rates}

One way of looking at the price and yield quotations on Treasury bill futures contracts in Table I is to interpret the yields on each futures contract as a market estimate of the three-month Treasury bill rate that is currently expected to prevail in each delivery month. Thus, the market's expectation on March 14, 1977, was that the three-month bill rate would be 5.23 percent in June of this year, and would increase another 126 basis points by December to 6.49 percent. In comparison, the three-month bill rate on March 14, 1977, for currently traded three-month bills, was about 4.57 percent.

However, such use of the Treasury bill futures rates is subject to some reservations. The main question is whether the futures rates are unbiased estimates of the market's expectations of future interest rates. According to the "normal backwardation" argument of Keynes and Hicks, futures prices are downward-biased estimates of expected future spot prices. ${ }^{5}$ This implies that even if future spot prices are expected to remain the same as the current spot price, the futures price will be below the expected spot price by an amount equal to a risk premimm. This premium is considered to be a return to speculators for assuming the risk of possible future price Huctuations, and is larger for delivery dates which extend further into the future. This implies, in turn, that the price of the futures contract will tend to rise (the yield will fall) as the delivery date ap. proaches, provided there is no change in market expectations.

In terms of futures markets in Treasury bills, the theory of "normal backwardation" implies that yields on futures contracts are upward-biased estimates of expected future interest rates (since prices and yields of securities are inversely related). Accordingly, the interest rate on three-month Treasury bills expected to prevail as of some future delivery date is less than the yield quoted on the futures contract for that

\footnotetext{
JJohn Maynard Keynes, A Treatise on Money: The Applied Theory of Money, vol. II (New York: Harcomt, Brace and Company, 1930), pp. 142-47; and J. R. Hicks, Value and Capital: An Inquiry into Some Fundamental Principles of Economic Theorty, 2nd ed. (Oxford: Clarendon Peess, 1946), pp. $136-39$.
} 


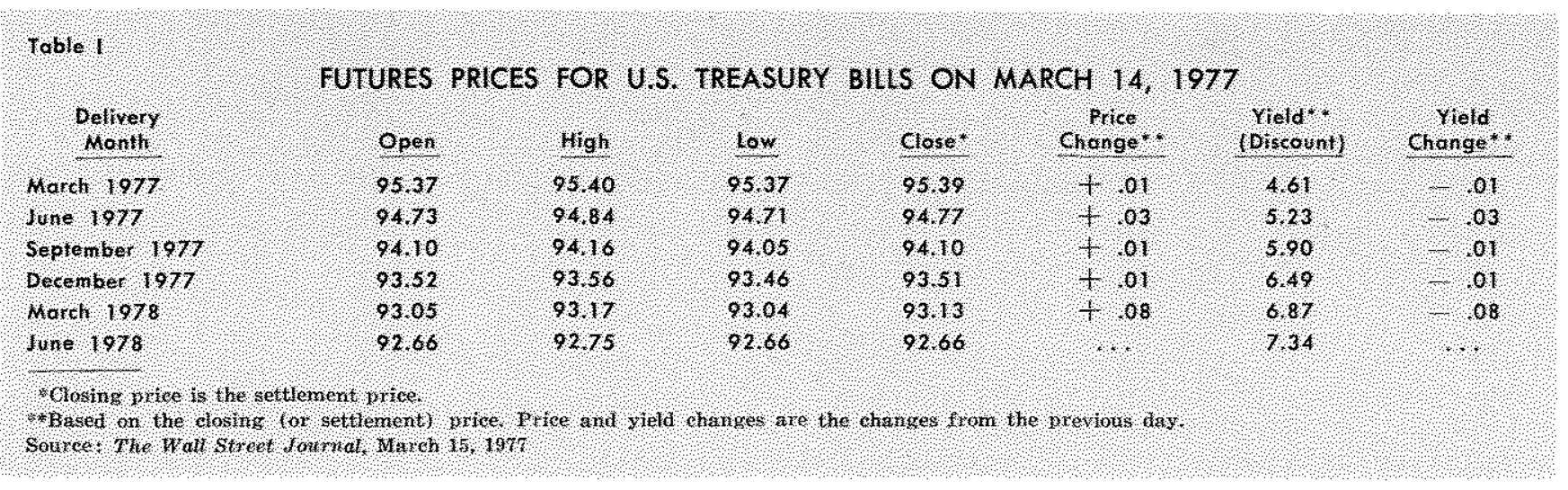

delivery date. ${ }^{6}$ In addition, if yields on futures contracts are higher for later delivery dates than for earlier delivery dates, it is not certain that the expected future spot rate is higher for the later deliv. ery dates than for the earlier delivery dates. This is because a larger risk premium is included in the yield associated with the later delivery dates. Only if the difference between the yields for an earlier and later delivery date exceed the difference between their risk premia can one conclude that the expected future spot rate is higher for the later delivery date.

One implication of this line of reasoning is that gradual declines in futures rates cannot necessarily be identified as declines in market expectations of future spot rates, since the yields on futures contracts tend to fall as the delivery date approaches. However, sharp declines indicate a change in expectations, as do increases in futures rates, provided the risk premia are constant or change very little (which is generally assumed by the theory).

If these risk premia could be easily estimated, market expectations of future interest rates could be estimated from quotations on futures contracts. Unfortunately, this is not the case. In addition, other analysts dispute the "normal backwardation" argument and claim that futures prices are unbiased estimates of expected future spot prices. The issues surround-

"Hicks used the "nommal backwardation" argument of the futures market in his development of the liquidity preference theory of the term structure of interest rates. See Hicks, Valte and Capital, Chapters XI and XIII. In the literature on the term structure, matket expectations of future interest rates have been examined using the implied forward rates which are embodied in the yield curve. These implied for" ward rates are theoretically equivalent to futures rates.

7For discussions of the issues involved and some empirical evidence in support of normal backwardation, see Hendrik $\mathbf{S}$. Houthakker, "Nomal Backwardation," in Value, Gapital and Growth: Papers in Honour of Sir John Hicks, ed. James N. Wolfe (Edinburgh: Edinburgh University Press, 1958), Chapter 7 , and "Can Speculators Forecast Prices?" The Review of Economics and Statistics (May 1957), pp. 143-51. For evidence against the theory of normal backwardation, see Lester ing this question of unbiasedness are not within the scope of this paper, but some observations on the matter can be made.

Even if futures rates are biased estimates of mar. ket expectations, the bias will not be very large, judging from the estimates of risk premia embodied in the yield curve. ${ }^{8}$ Furthermore, the bias, if it exists, is expected by most theorists to be consistent over time, rather than being subject to large fluctuations. Consequently, even though futures rates may not be entirely accurate as point estimates of market expectations, it may be possible to make rough estimates of expected future interest rates.

\section{Trading Volume}

Another issue bearing on the usefulness of the futures rates involves the amount of trading which occurs in each contract. Generally, it is thought that the larger the amount of trading in a security, the more representative the price and yield quotations

C. Telser, "Futures Trading and the Storage of Cotton and Wheat, Journal of Political Economy (June 1958), pp. 23355. Telser argues that prices of futures contracts are solely market expectations of future spot rates and contain no risk prenia.

8 Since such premia in the Treasury bill futures market will be, at most, for three-month bills eighteen months in the future, the bias in the yields on futures contracts will not be very large. This is due to the fact that the premia, according to the liquidity preference theory, increase with term-to-maturity for such Treasury bills. Thus, the premia associatod with three-month bills to be issued six months from today are expecked to be smaller than the premia associated with threemonth bills to be issued one year from today. Estimates of these premia have generally been less than 50 basis points. See f. Huston MoCulloch, "An Estimate of the Liquidity Preminm" Journal of Political Economy (February 1975), pp. 95-119; Roll, The Behavior of Interest Rates, pp. 98-99; and Edward J. Kane and Burton G. Malkiel, "The Term Structure of Interest Rates: An Analysis of a Survey of Interest-Rate Expectations," The Review of Economics and Statistics (August 1967), pp. 345-55.

The existence of a bias in the futures rates can be tested by investigating whether, with constant expectations, the prices of futures contracts rise (yields fall) as the delivery date approaches. 


\begin{tabular}{|c|c|c|c|c|c|c|c|c|c|c|c|c|}
\hline मिन्य & & & $A Y E A A$ & SEDA & $\begin{array}{l}\mathrm{RA} \\
\mathrm{Con}\end{array}$ & $\begin{array}{l}\mathrm{AP} \\
\mathrm{ben}\end{array}$ & $\begin{array}{l}1 \mathrm{NE} \\
\mathrm{Monhl}\end{array}$ & $1 \mathrm{MO}$ & & & & \\
\hline $\begin{array}{l}\text { Honts } \\
\text { traded }\end{array}$ & Kact: & $\begin{array}{l}\text { None } \\
1976\end{array}$ & $\mathrm{sep} / 9 \mathrm{mber}$ & 0 cembor & $\begin{array}{l}\text { Morth } \\
1977\end{array}$ & nue & $\begin{array}{l}\text { sepentser } \\
1977\end{array}$ & $\begin{array}{l}\text { Decenter } \\
\text { Q } 7 \mathrm{I}\end{array}$ & $\begin{array}{l}\text { Meret } \\
1578\end{array}$ & 1070 & $\begin{array}{l}\text { seftenbes } \\
1978\end{array}$ & $\begin{array}{c}\text { All } \\
\text { Issues }\end{array}$ \\
\hline 10000 n 1976 & 2895 & $36>9$ & en & 4,60 & & & & & & & & 18872 \\
\hline Fetron $19 t s$ & 58,89 & 41,3 & 21,4 & 127 & & & & & & & & 1348 \\
\hline $\mathrm{Manh} 1976$ & 27,6 & 182,39 & $>11$ & 2803 & 784 & & & & & & & 3069 \\
\hline$A+119+6$ & & 1410 & 120,4 & 3900 & 500 & & & & & & & 306.9 \\
\hline$M a \times 1976$ & & $\$ 200$ & 2245 & 8460 & 173 & 758 & & & & & & 42000 \\
\hline Wnelp & & 26,47 & 23014 & 2750 & 2736 & 10,45 & & & & & & 20107 \\
\hline $10 y=97$ & & & $2,4,4$ & 258,57 & 4305 & 8,43 & 7,7 & 605 & & & & 376,24 \\
\hline Avqust 1976 & & & 6073 & 27,50 & 68,04 & 1150 & 2,3 & 2,1 & & & & $4190 \%$ \\
\hline Seprenber 1976 & & & 1967 & 185,43 & 10,62 & 3981 & 400 & 310 & 200 & & & 36162 \\
\hline $0,60 \mathrm{ke} 1976$ & & & & 110,7 & 290,1 & 160,57 & 27,1 & 1519 & 429 & & & 61819 \\
\hline Howember 196 & & & & 5930 & 345,65 & 31540 & 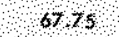 & 20,35 & 22,5 & & & 83100 \\
\hline 0, enter 1016 & & & & $3 \mathrm{mo}$ & 236,4 & 29481 & 1229 & 360 & 17,6 & & & 740,64 \\
\hline Manor 1077 & & & & & 21067 & 398,6 & 30133 & 74 & 3014 & 306 & & 103019 \\
\hline 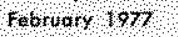 & & & & & 7832 & 4105 & 2120 & 8005 & 172 & 8,8 & & 85016 \\
\hline Mareh 1977 & & & & & 3659 & 35091 & 38004 & $1 \times 100$ & 5074 & 27,3 & 2767 & 1053,7 \\
\hline Apt1 1977 & & & & & & 232,5 & 5184 & 323,25 & 17210 & 7,15 & 2285 & $1 \leqslant, s, 05$ \\
\hline
\end{tabular}

will be of the market value of the security." In the case of Treasury bill futures contracts, this suggests that contracts with low trading volume are not representative of the market value of these contracts, and, hence, are not representative of market expectations. However, the issue is more complicated than this.

As can be seen from Table II, trading in any particular futures contract is low when it is first traded, increases over time, but then is again low as its delivery date approaches. For example, trading in the futures contract for delivery in March 1977 can be examined by reading down the appropriate column in Table II. This issue was first traded in March 1976, and the average daily volume of trading was only 7.84 contracts. By November 1976 , trading increased to over 345 contracts per day. But after January 1977, with less than two months to the delivery date, trading declined below 100 contracts per day.

As the delivery date approaches, trading volume generally declines because there is greater certainty as to what the spot rate will be on the delivery date. That is, traders tend to agree as to the future market value of three-month Treasury bills (their expectations become homogeneous) when the delivery date is near. Consequently, there is less risk of interest rate fluctuations to be hedged against and less likelihood that profits can be made from trading, so that less trading occurs. In this case, the futures rates do

\footnotetext{
9This line of reasoning underlies, in part, the construction of the Treasury Department's yield curves, which give greater weight to the yields of some actively traded issues.
}

reflect the market valuation of the contracts, even though there is little trading.

However, a lack of trading may also be indicative of a case where market participants have ill-defined expectations of future interest rates and their expectations are so diffuse that traders' bid or asked prices are not matched up with each other. In this case, there is little trading because there is great uncertainty as to the range in which the future spot rate will fall. It is possible that this case applies to the futures rates associated with contracts for delivery in fifteen to eighteen months, such as the March 1978 contract which was first traded in September 1976 (Table II).

On the other hand, when market participants have well-defined but heterogeneous expectations of future spot rates, trading activity is likely to be large. In this case, traders tend to agree as to the range in which the future spot rate will fall, but disagree as to the exact value. Market participants perceive that there is greater risk of interest rate fluctuations to be hedged against, and that profits can be made from trading. Bid and asked prices on contracts for the delivery date match up over a larger number of traders, and trading volume is larger.

Therefore, the extent to which the yields on futures contracts for particular delivery dates accurately reflect the market value of these contracts, and market expectations of future interest rates, depends upon the distribution of the expectations of traders. It is not simply a matter of the amount of trading in each contract. 
The volume of trading also reflects on the Treasury bill futures market as a whole. The volume of trading in futures contracts compares quite favorably with the volume of trading in the spot market for Treasury bills. The total volume of trading in the Treasury bill futures market was relatively light during the first two months of trading after its opening on January 6, 1976. But beginning in March 1976, trading inm creased substantially to an average daily volume of about 318 contracts (Table II). With each contract representing $\$ 1$ million of three-month bills, this trading represented the daily exchange of $\$ 318 \mathrm{mil}$ lion of Treasury securities in the futures market. In contrast, the average daily volume of trading by securtties dealers in the spot market for all outstanding Treasury bills (approximately forty different issues) was $\$ 6.76$ billion during March 1976. These figures average out to a daily volume of roughly $\$ 64$ million for each Treasury bill futures market issue (five issues were traded in March 1976), compared to about $\$ 169$ million for each outstanding Treasury bill issue in March 1976.

\section{MARKET EXPECTATIONS OF SHORT-TERM INTEREST RATES SINCE JANUARY 1976}

The pattern of yields on Treasury bill futures contracts since the initiation of trading on the International Monetary Market is shown on a daily basis in Chart 1. Examining the movement of these yields provides some insight into the adjustment of market expectations of future short-tem interest rates to new Information about the state of the econony and the future supply of and demand for credit. The chart shows that the yields on all of the futures contracts being traded during any particular time period follow the same pattem of movement to a remarkable degree.

During the first quarter of 1976 , market expecta tions of the future level of the three-month Treasury bill rate increased as the economy experienced a 9.2 percent anmual rate of growth in Real Gross National Product (GNP). With the economy growing at such a rapid pace, market participants apparently anticipated a continuation of this upswing in economic activity during the remainder of the year, although not at so fast a pace. This expected strength in economic activity was translated into anticipations of increased demands for short-term credit, with a consequent rise in interest rates. During March 1976, the yield on the September 1976 futures contract was generally above 6.50 percent, while the currently traded three-month Treasury bill yielded about 5 percent.

The yields on futures contracts declined during April 1976 , but by May yields had returned to roughly the same levels as were recorded in March (Chart I). During most of April 1976, newly available data indicated moderating pressures on the credit market and expectations of future levels of interest rates were revised downward. For example, the yields on the September 1976 futures contract during April were close to 6 percent, down from about 6.5 percent in March. Data on the money stock (M1) that became available in the first hall of April showed that the money stock had grown at a 2.9 percent rate over the first quarter of 1976 , well below the FOMC's announced target ranges for M1 growth. ${ }^{10}$ Most market participants apparently did not anticipate any nearterm tightening in monetary policy actions, and viewed the growth of money as being consistent with a continued gradual reduction of the longer-run inflationary impact of policy actions. The preliminary GNP data available in mid-April continued to show a slowing in inflation and a strong surge in real output growth. Business loan demand at commercial banks remained weak and Treasury financing requirements were ruming well below earlier estimates.

Beginning in late April 1976, however, there were several developments that acted to change market expectations, On April 22, market participants became aware that there had been a very shamp surge in $M 1$ in early April (money stock data is reported with a one-week lag). Data available in May indicated that the money stock was rising very rapidly, expanding at nearly a 17 percent annual rate in April and then at a 5.7 percent rate in May. On May 3 it was announced that the FOMC had voted at its April meeting to lower the upper band on the long-run growth of M1 from $7 / 2$ to 7 percent. ${ }^{11}$ The Federal Reserve moved to a more restrictive policy, and this was made apparent to market participants by a steady rise in the Federal funds rate from about 4.78 percent in the week ended April 23 to 5.02 percent in the week ended May 14. Then, at its May 18 meeting, the FOMC voted to adopt a Federal funds range of $5-5^{3 / 4}$ percent, compared to a $412-5 / 4$ percent range at the April meeting. By the week ended May 28 , the Federal funds rate had tisen to an average of

10Albert E. Burger and Douglas R. Mudd, "The FOMC in 1976: Progress Against milation," this Review (March 1977), pp. 2-17.

11 Ibid. Rates of growt of the money stock used in this paper are the originally reported figures, not the subsequently revised figures. 


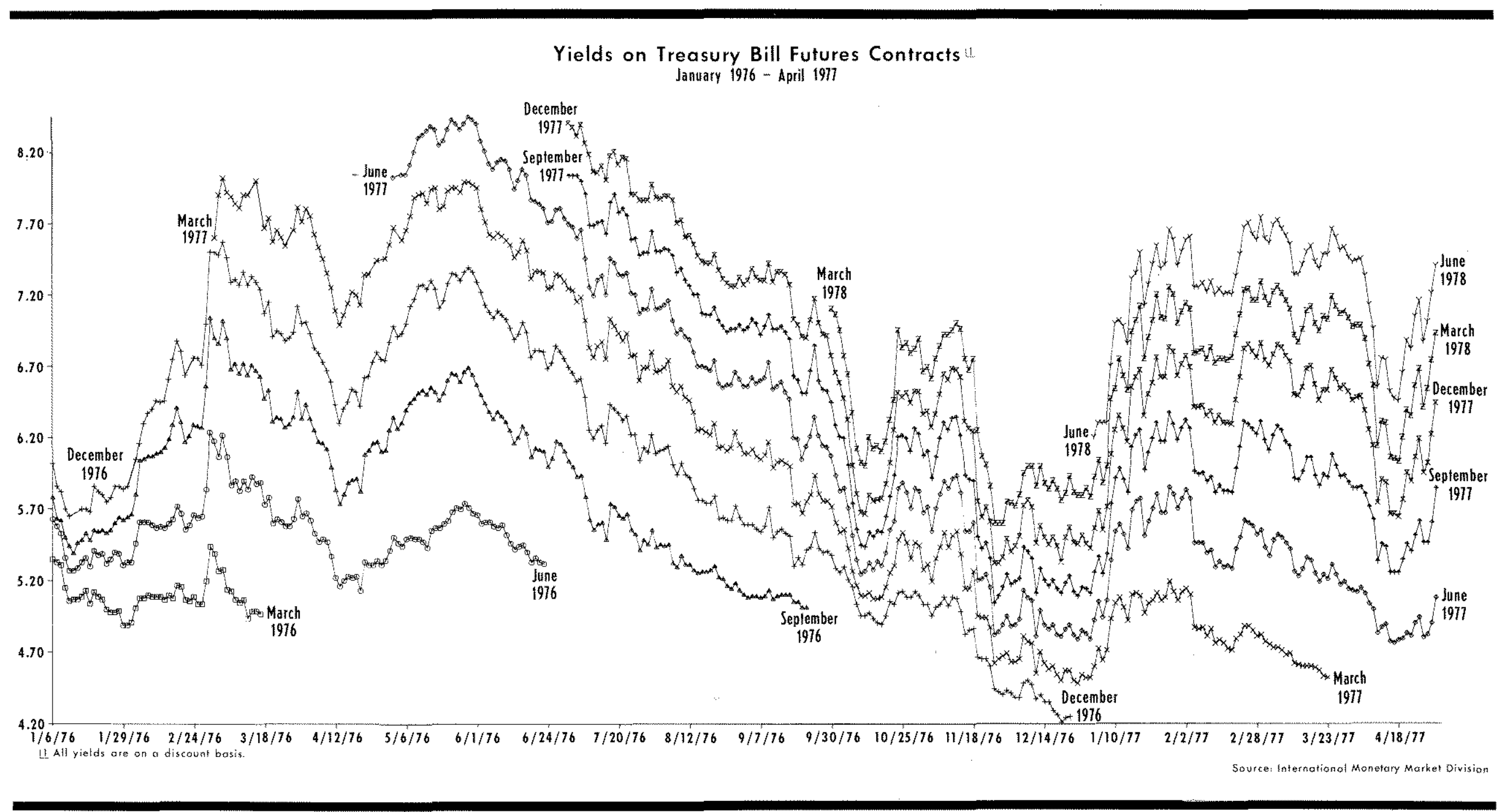


5.50 percent. As this new information about the course of monetary developments became available, market anticipations of future levels of interest rates returned by late May to about the same level as was recorded in March 1976.

The expected increase in credit demand failed to appear, GNP growth remained moderate, the inflation rate declined, and the unemployment rate increased during the summer of 1976. Growth of the money stock fell to about a 3 percent rate from May to September. Yields on futures contracts and the spot rate on three-month bills both declined slowly from late May until early October, ${ }^{12}$ when the yields on futures contracts fell quite sharply. This sharp decline was reversed in late October when yields increased almost to their early September levels. This reversal in expected yields was also associated with incoming monetary data that indicated a sharp surge in the rate of growth of the money stock. From September to October, M1 increased at a 15.5 percent amnual rate.

Indicators of the strength of economic activity continued to decline during the last quarter of 1976, as did the rate of inflation, and market interest rates on all types of securities continued to decline. In the last half of November, market expectations of future interest rates declined sharply. After the surge in M1 growth during October, the money stock was little changed during November. But the Federal funds rate declined from about 5 percent in early November to about 4.75 percent in early December, which, in turn, was interpreted by market participants as indicating that the Federal Reserve had adopted a somewhat less restrictive policy. During November, yields on futures contracts fell 50 basis points or more. With pessimism about the "pause" in the economy mounting, yields on futures contracts for Treasury bills continued to fluctuate around these lower levels until the end of the year.

The increase in expected future interest rates in early January 1977 coincided with the new Administration's announcement of a stimulative fiscal package. At the same time, data on the economic indicators for November were revised upward and a strong showing of some of the indicators for December was reported. Furthermore, monetary actions were no longer moving toward a further reduction in the

12 Under the "normal backwardation" hypothesis, this gradual decline in futures rates may not reflect a gradual decline in market expectations of future spot rates. Instead, such a gradual decline over time is consistent with constant market expectations of future spot rates, since if "nommal backwarda" tion" holds, futures rates tend to fall (futures prices rise) as the contract delivery date approaches.
Federal funds rate, contrary to the initial expectations of many market analysts. As a result, yields on futures contracts increased to their levels of mid-October through early November.

From early January through March 1977, yields on futures contracts were relatively stable. During April, when the Administration's rebate program was cancelled and the energy program was announced, futures rates fluctuated sharply. As new information on the state of the economy and on future supplies and demands for credit becomes available to market participants, the expected future interest rates that are embodied in the yields on future contracts for U.S. Treasury bills will be revised. Movements in the levels of these yields will, therefore, provide a significant indicator of revisions of market expectations of future short-term interest rates.

\section{SUMMARY AND CONCLUSIONS}

The Treasury bill futures market provides a means for hedging against interest-rate risk. Speculators are allowed the opportunity of making profits in this market in return for bearing the risk of future interest rate fluctuations. In addition, futures markets provide information about the expected future pattern of prices. In doing so, indications of changes in market expectations of future short-term interest rates can be obtained. Although exact estimates of the expected level of future spot rates may not be obtainable from futures rates without adjusting for a risk premium, an approximation of the level is possible.

If it can be shown that futures rates are unbiased estimates of expected future interest rates, the data from the Treasury bill futures market could be very useful in a number of ways. Policymakers would be able to readily assess the effects of policy changes on market expectations of future interest rates. Economists and other researchers would have observable values for market expectations of interest rates, instead of having to use proxy variables for such expected rates. Analyses of the portfolio behavior of financial intermediaries, investment decisions of firms, and the term structure of interest rates are among the many areas of research which would be aided by the use of such data. In addition, analysts who forecast interest rates would be able to compare their estimates of future interest rates against the market's expectations. Since market expectations of interest rates are an important factor in many economic relationships, the information on expectations contained in the Treasury bill futures market will be of increasing interest to businessmen, financial managers, policymakers, and other economic analysts. 